\title{
Intercontinental transport and deposition patterns of atmospheric mercury from anthropogenic emissions
}

\author{
L. Chen ${ }^{1}$, H. H. Wang ${ }^{1}$, J. F. Liu ${ }^{1}$, Y. D. Tong ${ }^{1}$, L. B. Ou ${ }^{1}$, W. Zhang ${ }^{2}$, D. Hu ${ }^{1}$, C. Chen ${ }^{1}$, and X. J. Wang ${ }^{1}$ \\ ${ }^{1}$ Ministry of Education Laboratory of Earth Surface Processes, College of Urban and Environmental Sciences, \\ Peking University, Beijing 100871, China \\ ${ }^{2}$ School of Environment and Natural Resources, Renmin University of China, Beijing 100872, China \\ Correspondence to: W. Zhang (zhw326@ ruc.edu.cn) and X. J. Wang (xjwang@urban.pku.edu.cn)
}

Received: 26 July 2013 - Published in Atmos. Chem. Phys. Discuss.: 28 September 2013

Revised: 20 July 2014 - Accepted: 25 August 2014 - Published: 24 September 2014

\begin{abstract}
Global policies that regulate anthropogenic mercury emissions to the environment require quantitative and comprehensive source-receptor relationships for mercury emissions, transport and deposition among major continental regions. In this study, we use the GEOS-Chem global chemical transport model to establish source-receptor relationships among 11 major continental regions worldwide. Source-receptor relationships for surface mercury concentrations (SMC) show that some regions (e.g., East Asia, the Indian subcontinent, and Europe) should be responsible for their local surface $\mathrm{Hg}(\mathrm{II})$ and $\mathrm{Hg}(\mathrm{P})$ concentrations due to near-field transport and deposition contributions from their local anthropogenic emissions (up to 64 and $71 \%$ for $\mathrm{Hg}$ (II) and $\mathrm{Hg}(\mathrm{P})$, respectively, over East Asia). We define the region of primary influence (RPI) and the region of secondary influence (RSI) to establish intercontinental influence patterns. Results indicate that East Asia is the SMC RPI for almost all other regions, while Europe, Russia, and the Indian subcontinent also make some contributions to SMC over some receptor regions because they are dominant RSI source regions. Source-receptor relationships for mercury deposition show that approximately 16 and $17 \%$ of dry and wet deposition, respectively, over North America originate from East Asia, indicating that transpacific transport of East Asian emissions is the major foreign source of mercury deposition in North America. Europe, Southeast Asia, and the Indian subcontinent are also important mercury deposition sources for some receptor regions because they are the dominant RSIs. We also quantify seasonal variation on mercury deposition contributions over other regions from East Asia. Results show that mercury deposition (including dry and wet) contri-
\end{abstract}

butions from East Asia over the Northern Hemisphere receptor regions (e.g., North America, Europe, Russia, the Middle East, and Middle Asia) vary seasonally, with the maximum values in summer and minimum values in winter. The opposite seasonal pattern occurs on mercury dry deposition contributions over Southeast Asia and the Indian subcontinent.

\section{Introduction}

Mercury, known as a global pollutant, can be transported across continents and oceans. The long atmospheric lifetime (about 1 year) of elemental $\mathrm{Hg}(0)$, which makes up approximately $95-99 \%$ of atmospheric mercury, contributes to the long distance transport (Schroeder and Munthe, 1998). The remaining mercury consists of gaseous soluble $\mathrm{Hg}(\mathrm{II})$ and nonvolatile particulate $\operatorname{Hg}(\mathrm{P})$, which are the major contributors to dry and wet deposition of atmospheric mercury (Corbitt et al., 2011). Once deposited into ecosystems, mercury bioaccumulation and methylation in food webs may occur and adversely affect human health, especially infants, who could suffer immune system suppression or neurodevelopmental delays (Rolfhus et al., 2003; Mergler et al., 2007; Selin et al., 2010). Because of anthropogenic emissions from human activities, atmospheric mercury deposition to continents and oceans has increased threefold over the past several centuries (Schuster et al., 2002; Roos-Barraclough et al., 2002; Fitzgerald et al., 2005). Growing concerns about increased environmental mercury have promoted the launch of the Minamata Convention on Mercury which was adopted at the Conference of Plenipotentiaries in Kumamoto and 
signed by over 90 countries in 2013 (Minamata Convention on Mercury, 2014). United Nations Environment Programme (UNEP) released the 2013 global mercury assessment report and its technical background report (AMAP(Arctic Monitoring and Assessment Programme)/UNEP, 2013; UNEP, 2013). These reports will help improve our knowledge of the biogeochemical cycle of mercury and contribute to the reduction of mercury pollution. Global policies that regulate anthropogenic mercury emissions to the environment require an understanding of source-receptor relationships for mercury emissions, transport and deposition among major continental regions worldwide. In order to establish recommendations to protect human health and ecosystems on a global scale, the Global Mercury Observing System (GMOS), a coordinated global observation system for mercury, is under development (GMOS, 2014). This international program can provide highquality data for the validation and application of regional and global scale atmospheric models, and give a firm basis for future policy development and implementation.

Studies below have presented some source-receptor relationships on regional and intercontinental scales. Transpacific transport of mercury from East Asia, attributed to circumpolar westerlies in the midlatitudes, contributes to mercury deposition in North America (Seigneur et al., 2004; Selin and Jacob, 2008; Strode et al., 2008). Jaffe and Strode (2008) demonstrated that most $\mathrm{Hg}(\mathrm{II})$ and $\mathrm{Hg}(\mathrm{P})$ from Asian emissions were removed in Asia, but most $\mathrm{Hg}(0)$ from Asian emissions was transported long distance and Asian anthropogenic sources contributed to 7-20\% (average 16\%) of mercury deposition in North America. Zhang et al. (2012) indicated that $10-22 \%$ and $13-20 \%$ of mercury wet and dry deposition in the US originated from North American anthropogenic sources, respectively. Lin et al. (2010) investigated mercury emission outflow from East Asia using a chemical transport model alongside a coupling with mass balance analyses, and showed that $75 \%$ of mercury emissions from East Asia were transported outside the region and contributed to $20-30 \%$ of mercury deposition at remote receptors. They also claimed that global anthropogenic sources accounted for $75 \%$ of mercury deposition in East Asia, with $25 \%$ from natural sources. Philip et al. (2007) estimated that mercury deposition in North America was $335 \mathrm{Mg}$ in 2002, and the net outflow to the global pool was $21 \mathrm{Mg}$. Li Pan et al. (2010) showed that mercury mass outflow (approximately $681-714 \mathrm{Mg} \mathrm{a}^{-1}$ ) constituted $70 \%$ of mercury emissions from East Asia, with the highest outflow during spring and early summer. The Task Force on Hemispheric Transport of Air Pollution (TFHTAP) published its first comprehensive report in 2010 and reported some source-receptor relationships of mercury deposition among continents in the Northern Hemisphere (Europe, North America, East Asia, and South Asia) (TFHTAP, 2011). Although the literature studies above have shown some source-receptor relationships among regions, establishment of quantitative and comprehensive influence patterns among major continental regions is needed. Previous studies also focused mainly on selected continental regions (e.g., East Asia, North America, and Europe), with little attention focused on other regions which were also critical (e.g., India, Southeast Asia, and Russia). Also, mercury emissions from other regions could also influence mercury concentrations and deposition in East Asia, which draws little research attention.

Quantitative and comprehensive influence patterns among major continental regions for some air pollutants (e.g., aerosols, $\mathrm{O}_{3}$, and nitrogen deposition) have been established in previous studies (Chin et al., 2007; Liu and Mauzerall, 2007; Liu et al., 2009a, b). Chin et al. (2007) used a global model to estimate the impact of dust aerosols from source regions on surface aerosol concentrations on regional and hemispheric scales, and identified influence patterns among Asia, North America, Europe, and Africa. They demonstrated that African and European dust could be transported eastwards, where it merged with Asian dust and was subsequently transported across the North Pacific to western North America. Liu et al. (2009a, b) described a method for tagging tracers and evaluated intercontinental transport of fine aerosols using the definition of region of primary influence (RPI). Subsequently, they estimated global premature mortality resulting from intercontinental transport of fine aerosols. Relative to quantitative and comprehensive influence patterns for some other air pollutants, a quantitative and comprehensive understanding of influence patterns for mercury is needed.

In this study, we use the GEOS-Chem global chemical transport model to evaluate intercontinental transport and deposition patterns of atmospheric mercury from anthropogenic emissions. This study aims to (1) simulate the global distributions of mercury concentrations and deposition, and estimate the global budget of atmospheric mercury; (2) establish quantitative and comprehensive source-receptor relationships for mercury emissions, transport and deposition among major continental regions worldwide.

\section{Methods}

\subsection{Model description}

We use the GEOS-Chem global mercury model version 901-03 (http://acmg.seas.harvard.edu/geos/), including a 3-D atmosphere model coupled to 2-D ocean and terrestrial reservoirs (Selin et al., 2008; Holmes et al., 2010; Soerensen et al., 2010; Amos et al., 2012). Simulations are conducted with $2^{\circ} \times 2.5^{\circ}$ horizontal resolution and 47 vertical hybrid eta levels from the surface to $0.01 \mathrm{hPa}$. The simulations are driven by assimilated meteorological fields from the NASA Goddard Earth Observing System (GEOS-5) and conducted for 2004-2011, with the year 2004 used for initialization and the years 2005-2011 for analysis. As such, all results presented here are 7-year averages, which can approximately represent 
average global atmospheric mercury conditions during this period. Three inorganic mercury forms, including elemental $\mathrm{Hg}(0)$, gaseous soluble $\mathrm{Hg}(\mathrm{II})$ and nonvolatile particulate $\mathrm{Hg}(\mathrm{P})$, are tracked by the atmospheric simulations.

In GEOS-Chem model version 9-01-03, we have two alternative options to mercury model (the mercury $+\mathrm{OH} / \mathrm{O}_{3}$ model from Selin et al. (2007) or the mercury + Br model from Holmes et al., 2010), and we choose the mercury $+\mathrm{Br}$ model. With oxidation of $\mathrm{Hg}(0)$ by $\mathrm{Br}$ atoms and photoreduction of $\mathrm{Hg}(\mathrm{II})$ in cloud droplets, the mercury $+\mathrm{Br}$ model can reproduce most observations and improve predictions of mercury interhemispheric gradient and mercury concentrations in polar regions (Holmes et al., 2010). In addition, considerable uncertainties in $\mathrm{Hg}(0)$ oxidation mechanisms and the associated kinetics of the mercury $+\mathrm{OH} / \mathrm{O}_{3}$ model (Calvert and Lindberg, 2005; Hynes et al., 2009; Subir et al., 2011) also contribute to the choice of the mercury $+\mathrm{Br}$ model. Mercury dry deposition and wet scavenging in GEOS-Chem follow the resistance-in-series scheme from Wesely (1989) and the scheme from Liu et al. (2001), respectively. The atmospheric lifetime of mercury against dry deposition is increased with the partitioning between $\mathrm{Hg}(\mathrm{II})$ and $\mathrm{Hg}(\mathrm{P})$ discussed below. Wet scavenging processes include washout losses in convective updrafts and rainout losses in large-scale precipitation. According to recent GEOS-Chem improvements by Wang et al. (2011), rainout and washout occur in same grid cell and the schemes of aerosol scavenging by snow and rain are different. When supercooled water freezes in clouds, both $\mathrm{Hg}(\mathrm{II})$ and $\mathrm{Hg}(\mathrm{P})$ remain (Holmes et al., 2010; Wang et al., 2011). Because of inefficient scavenging of $\mathrm{Hg}$ (II) by snow (Keeler et al., 2005; Sigler et al., 2009; Lombard et al., 2011), we only include below-cloud scavenging of $\mathrm{Hg}(\mathrm{P})$ by snow (Holmes et al., 2010; Amos et al., 2012; Zhang et al., 2012). The uptake of $\mathrm{Hg}$ (II) by sea-salt aerosol as $\mathrm{Hg}-\mathrm{Cl}$ complexes and their subsequent deposition in the surface ocean are also included in this study (Holmes et al., 2009, 2010).

Some amendments and developments relative to previous GEOS-Chem versions (e.g., v8-03-02, and v9-01-02) affecting mercury simulations are present in v9-01-03. First, the gross flux mechanism of $\mathrm{Hg}(0)$ across the air-sea interface has been corrected. Soerensen et al. (2012) suggested that if the seawater was undersaturated, the evasion flux would be negative, which was only considered from air to sea. However, downward evasion (only $2 \%$ of upward evasion) rarely occurred because seawater was mostly supersaturated with $\mathrm{Hg}(0)$. Second, instead of partitioning $\mathrm{Hg}(\mathrm{II})$ in a $1: 1$ ratio for the gas and particle phases, Amos et al. (2012) introduced a function based on local air temperature and aerosol burden to modify $\mathrm{Hg}$ (II) partitioning between the two phases. Using this function, $\operatorname{Hg}(\mathrm{P})$ ranged from less than $10 \%$ in warm air and low aerosol loading, to more than $90 \%$ in cold air and high aerosol loading. With these developments, model simulations of mercury wet deposition and $\mathrm{Hg}(\mathrm{P})$ concentrations at observational sites in the US were improved (Amos et al., 2012; Soerensen et al., 2012).

\subsection{Emissions}

The AMAP/UNEP anthropogenic mercury emission inventory for the year 2005 (Pacyna et al., 2010) is used in this study. This inventory includes $\mathrm{Hg}(0), \mathrm{Hg}(\mathrm{II})$, and $\mathrm{Hg}(\mathrm{P})$ at 1320, 480 and $130 \mathrm{Mg} \mathrm{a}^{-1}$, respectively, with a horizontal resolution of $1^{\circ} \times 1^{\circ}$ and no seasonal variation. Combustion of fossil fuels (primarily coal) accounts for $46 \%$ of the total anthropogenic emissions, making it the largest emission source from human activities. The inventory includes artisanal/small-scale gold mining that is not included in previous inventories (Pacyna et al., 2006; Wilson et al., 2006), but is responsible for $18 \%$ of anthropogenic emissions. The inventory indicates that Asian sources release approximately two-thirds of global anthropogenic mercury emissions, with China as the largest source region worldwide. Although the US and India are the second and third highest contributors, respectively, their emissions combined are only $30 \%$ those of China.

According to the findings from Amos et al. (2012) and Zhang et al. (2012), we adjust the mercury emission speciation. Amos et al. (2012) assumed that $\mathrm{Hg}(\mathrm{P})$ was emitted as semi-volatile $\mathrm{Hg}$ (II) rather than as refractory, and merged it with $\mathrm{Hg}(\mathrm{II})$ emissions. The adjustment considerably improved their model simulations of $\operatorname{Hg}(\mathrm{P})$ at observational sites. Although its chemical mechanism has not been identified (Lohman et al., 2006), in-plume reduction of $\mathrm{Hg}$ (II) emitted from power plants has been confirmed in previous model studies (Seigneur et al., 2003, 2006; Lohman et al., 2006; Vijayaraghavan et al., 2008; Kos et al., 2011; Zhang et al., 2012). In addition, Edgerton et al. (2006) observed that $\mathrm{Hg}(0)$ accounted for about $84 \%$ of total mercury emissions from power plant plumes at three surface sites. Therefore, Zhang et al. (2012) substituted an $86.5: 9.9: 3.6$ $(\mathrm{Hg}(0): \mathrm{Hg}(\mathrm{II}): \mathrm{Hg}(\mathrm{P}))$ speciation for the $50: 40: 10$ speciation used for fossil fuel combustion, which comprised $46 \%$ of the total anthropogenic emissions in the inventory from Pacyna et al. (2010), and demonstrated significant improvements of their in-plume reduction simulations while comparing with the mercury concentrations observed at 19 surface sites and wet deposition observed at MDN sites. Here, we use the same principles as Amos et al. (2012) and Zhang et al. (2012). In order to evaluate the validity of the application of the mercury speciation data on a global scale, comparisons between the observed and modeled total gaseous mercury (TGM) concentrations under simulations with and without in-plume reduction are conducted. 


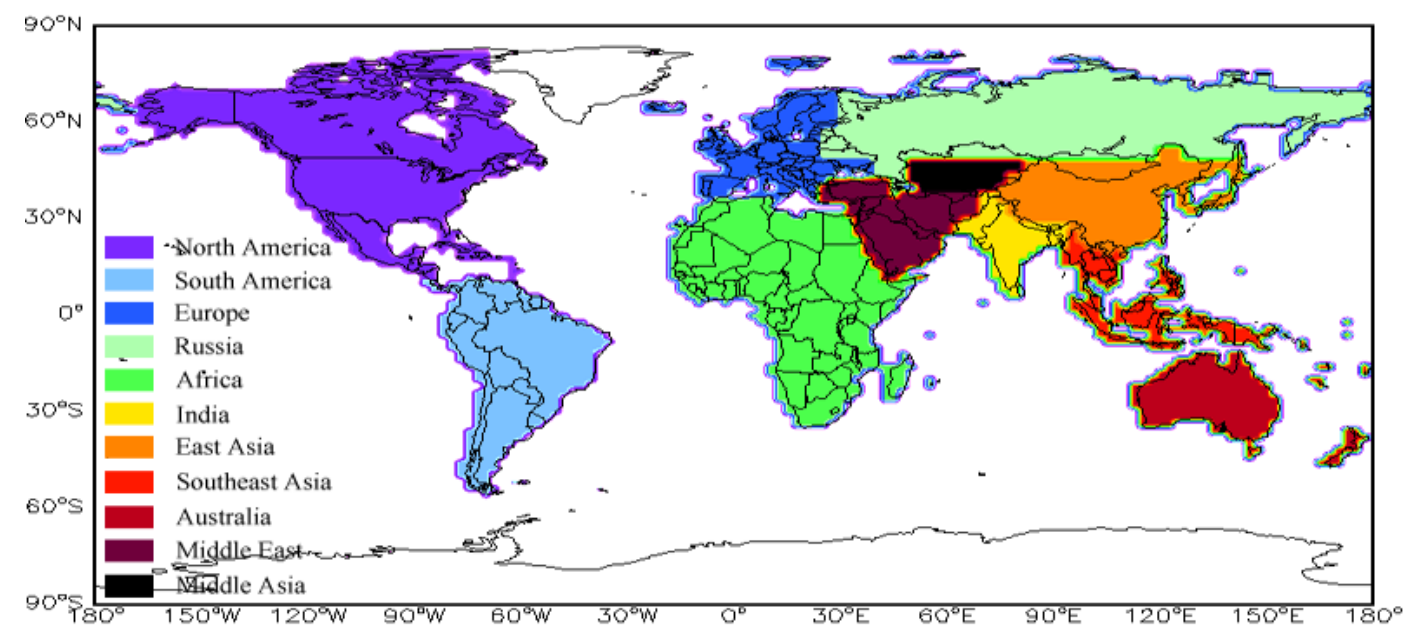

Figure 1. The 11 continental regions tagged in our GEOS-Chem simulations.

\subsection{Tagged regional tracers}

$\mathrm{Hg}(0), \mathrm{Hg}(\mathrm{II})$, and $\mathrm{Hg}(\mathrm{P})$ (which is emitted as $\mathrm{Hg}(\mathrm{II})$ ) are tagged by defined regions when they are emitted. To establish quantitative and comprehensive source-receptor relationships for mercury emissions, transport and deposition on intercontinental scales, 11 continental regions are defined, as shown in Fig. 1: North America (NA), South America (SA), Europe (EU, excluding the portion of Russia in the European domain), Russia (RU), Africa (AF), the Indian subcontinent (IN), East Asia (EA), Southeast Asia (SE), Australia (AU), Middle East (ME), and Middle Asia (MA). In addition, a tracer (denoted as "Nature") is used to represent the emissions from natural sources (e.g., oceanic emissions, land reemissions, and primary natural emissions, Selin et al., 2007) and untagged regions in Fig. 1. Figure 2 compares the magnitudes of $\mathrm{Hg}(0), \mathrm{Hg}(\mathrm{II})$, and $\mathrm{Hg}(\mathrm{P})$ anthropogenic emissions from the 11 continental regions. Globally, mercury emissions from EA are the dominant anthropogenic source in the world, and the $\mathrm{Hg}(0), \mathrm{Hg}(\mathrm{II})$ and $\mathrm{Hg}(\mathrm{P})$ emissions account for 48,48 and $47 \%$ of the global values respectively. The procedure of tagging tracers does not perturb the physical and chemical processes of the model. To evaluate the tagging procedure, we run a base case simulation that is a completed global simulation with no tagging procedure. The sum of concentrations or fluxes originating from tagged tracers (including the 11 continental tagged regions and nature) is compared with those obtained under the base case simulation over a given continental region. Generally, the differences in most regions are less than $1 \%$, with up to $3 \%$ in a few regions. We attribute the large discrepancy ( $3 \%$ ) to nonlinear calculations in some processes of the model, such as convection, diffusion, partitioning and chemical reactions. The small nonlinear calculations do not affect the implications of our tagging procedure and the analysis of our results.

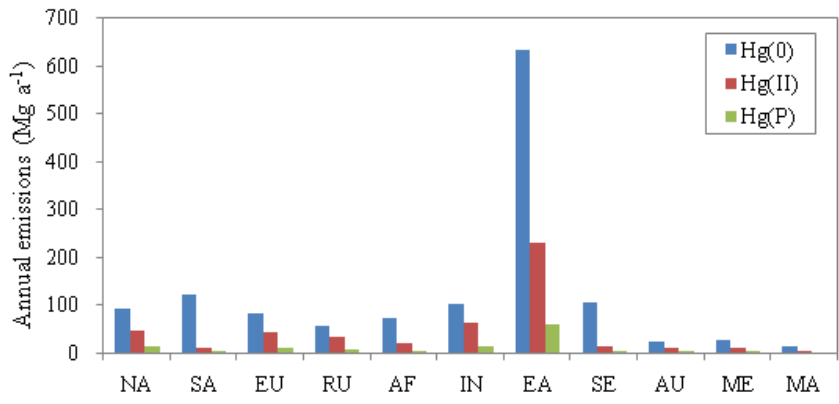

Figure 2. Tagged regional anthropogenic mercury emissions.

\section{Results and discussion}

Surface mercury concentrations (SMC) (including $\mathrm{Hg}(0)$, $\mathrm{Hg}(\mathrm{II})$ and $\mathrm{Hg}(\mathrm{P})$ ) and mercury deposition (including dry and wet deposition) are discussed in this section. The surface layer in GEOS-Chem is at the bottom of the troposphere, which averages $120 \mathrm{~m}$ high and is where most human activities occur. The SMC and mercury deposition fluxes are averaged from 2005 to 2011 to approximately represent the average conditions during this period.

We run a base case simulation with no tagging procedure to evaluate the model with comparisons between observed and modeled TGM concentrations. Meanwhile, the global distributions and budget of atmospheric mercury are obtained. Then we quantify and compare source-receptor relationships for SMC and mercury deposition among the 11 continental regions with the tagging procedure.

\subsection{Model evaluation}

The model is evaluated through comparisons with a series of observations worldwide including surface air mercury concentrations from the Canadian Atmospheric Mercury 


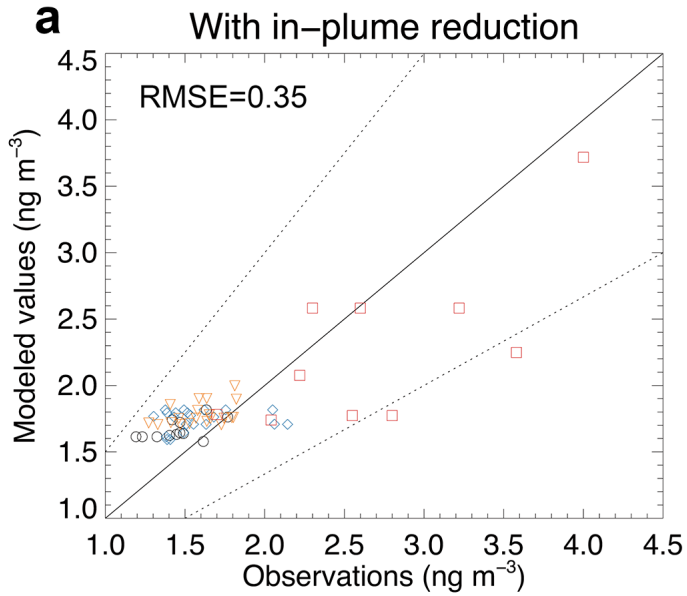

CAMNet sites AMNet sites

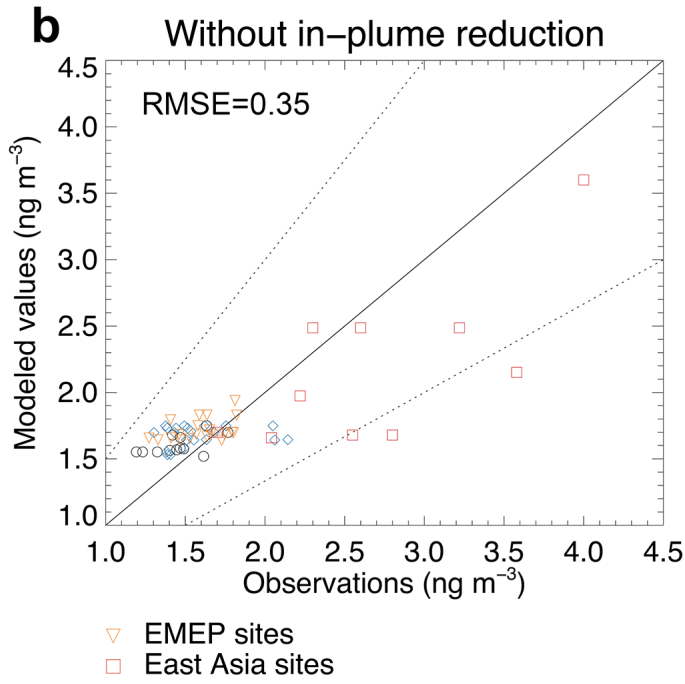

Figure 3. Scatter plot of observed and modeled TGM concentrations under two scenarios: (a) In-plume reduction is used globally; (b) Inplume reduction is not used. The solid line indicates the $1: 1$ line, while the dashed lines correspond to $\pm 50 \%$. The RMSE (root-mean-square error) for each scenario is shown.

Measurement Network (CAMNet, 2011), the Atmospheric Mercury Network (AMNet, 2009) and the European Monitoring and Evaluation Programme (EMEP, 2013). Some observations from previous studies conducted in East Asia are also involved in this comparison (Wang et al., 2007; Chand et al., 2008; Fu et al., 2008a, b, 2010; Kim et al., 2009; Wan et al., 2009a, b; Ci et al., 2011a, b; Zhang, 2011). Some observational sites from these networks and East Asia are also involved in GMOS (GMOS, 2014). We select the observational data during 2005-2011 and average the data through the period for each site. The root-mean-square error (RMSE) which is a frequently used measure of the differences between observed and modeled values is used to measure the performance of the model.

Figure $3 \mathrm{a}$ and $\mathrm{b}$ show the comparisons between the observed and modeled TGM concentrations under the simulations with and without in-plume reduction, respectively. Figure $3 \mathrm{a}$ indicates that the model is able to reproduce the atmospheric mercury concentrations. But for high TGM concentrations in East Asia, the modeled values are somewhat underestimated. A comparison between the two panels indicates that the simulation with in-plume reduction performs as well as the simulation without in-plume reduction on a global scale. They have the same RMSE values (Fig. 3). Therefore, the changes in the mercury speciation data derived from Zhang et al. (2012) are valid worldwide. In order to keep the emission speciation between North America and other continental regions uniform, we adopt the data from Zhang et al. (2012) to conduct global simulations. Comparisons between the observed and modeled values show that the model can be used to simulate the global distributions and budget of atmospheric mercury, and establish the source-receptor relationships in this study.

\subsection{Global distributions of mercury concentrations and deposition}

The global spatial distributions of annual average SMC are shown in Fig. 4a-c. Figure 4d-f illustrate the global spatial distributions of annual average mercury dry deposition, wet deposition and total deposition (dry + wet), respectively. The surface $\mathrm{Hg}(0)$ concentrations resemble the spatial emission pattern from the AMAP/UNEP emission inventory, with a footprint of dominant anthropogenic source regions (e.g., East Asia, the Indian subcontinent, and Europe). The modelpredicted surface $\mathrm{Hg}(0)$ concentrations in this study range from 0.9 to $4.3 \mathrm{ng} \mathrm{m}^{-3}$, consistent with the results from Holmes et al. (2010). Figure 4a reveals a considerably strong interhemispheric gradient of surface $\mathrm{Hg}(0)$ concentrations, which has also been shown from cruise data (Lamborg et al., 2002; Temme et al., 2003) and previous model predictions (Selin et al., 2007). The zonal mean interhemispheric ratio at the surface is 1.4 for $\mathrm{Hg}(0)$ concentrations, similar to the value of 1.2 found for total gaseous mercury concentrations by Selin et al. (2007). Furthermore, a strong concentration gradient from East Asia to the Pacific Ocean is evident in Fig. 4a, suggesting the possibility of transpacific transport of mercury, similar to the findings from Jaffe and Strode (2008) and Lin et al. (2010). Compared to the accumulation of $\mathrm{Hg}(\mathrm{II})$ and $\mathrm{Hg}(\mathrm{P})$ in the upper troposphere and stratosphere (Selin et al., 2007; Lyman and Jaffe, 2012), the concentrations of $\operatorname{Hg}(\mathrm{II})$ and $\mathrm{Hg}(\mathrm{P})$ at the surface layer are low because of the rapid deposition. High surface $\mathrm{Hg}$ (II) concentrations occur in polar regions, likely because of high $\mathrm{Br}$ atoms concentrations and $\operatorname{Hg}(0)$ oxidation rates during the atmospheric mercury depletion events (AMDEs) in spring in 
a Surface $\operatorname{Hg}(0)$ concentrations
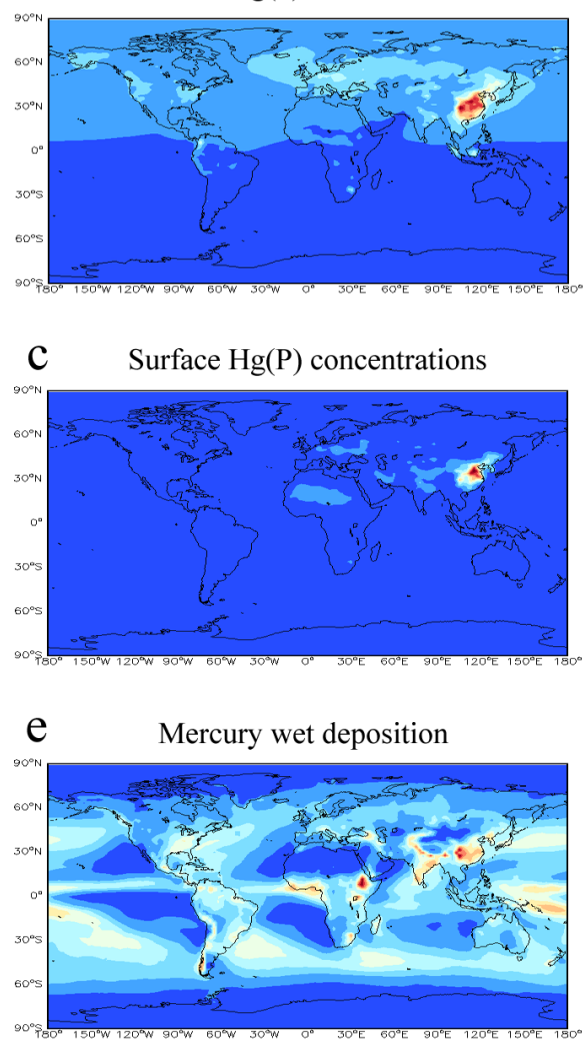

b
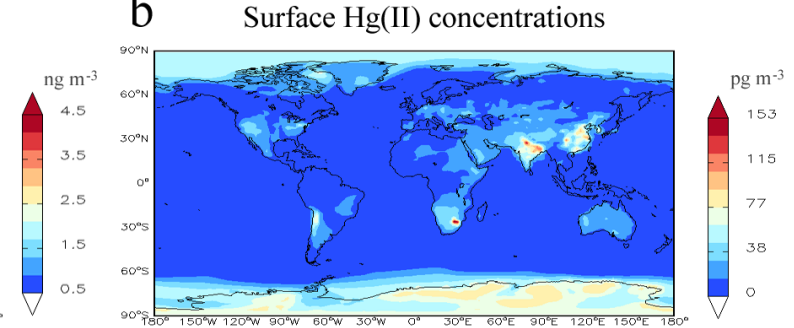

d
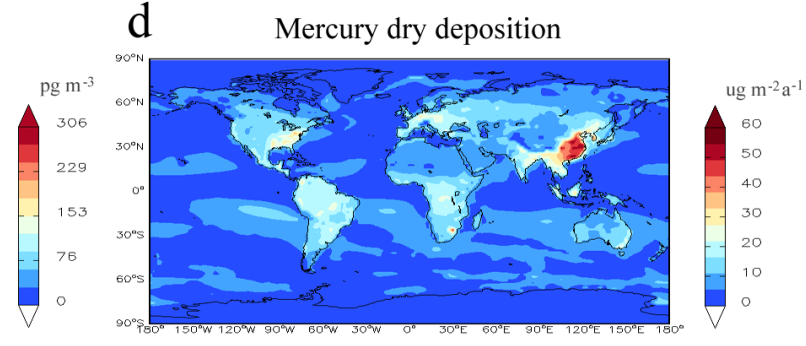
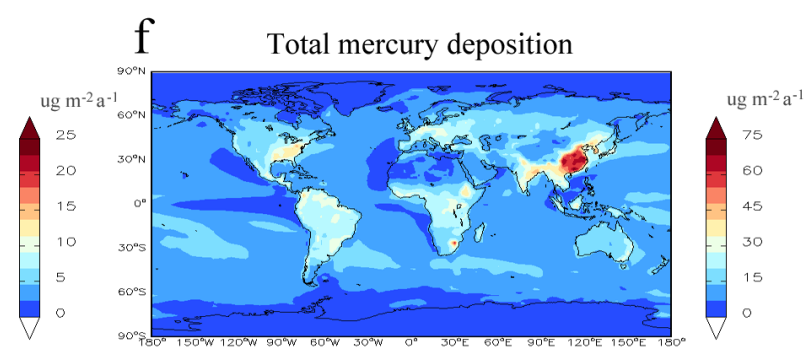

Figure 4. Global spatial distributions of annual average SMC and mercury deposition: (a) surface $\mathrm{Hg}(0)$ concentrations; (b) surface $\mathrm{Hg}(\mathrm{II})$ concentrations; (c) surface $\mathrm{Hg}(\mathrm{P})$ concentrations; (d) mercury dry deposition $(\mathrm{Hg}(0)$ dry deposition $+\mathrm{Hg}(\mathrm{II})$ dry deposition $+\mathrm{Hg}(\mathrm{P})$ dry deposition); (e) mercury wet deposition ( $\mathrm{Hg}(\mathrm{II})$ wet deposition $+\mathrm{Hg}(\mathrm{P})$ wet deposition); (f) total mercury deposition (dry deposition + wet deposition).

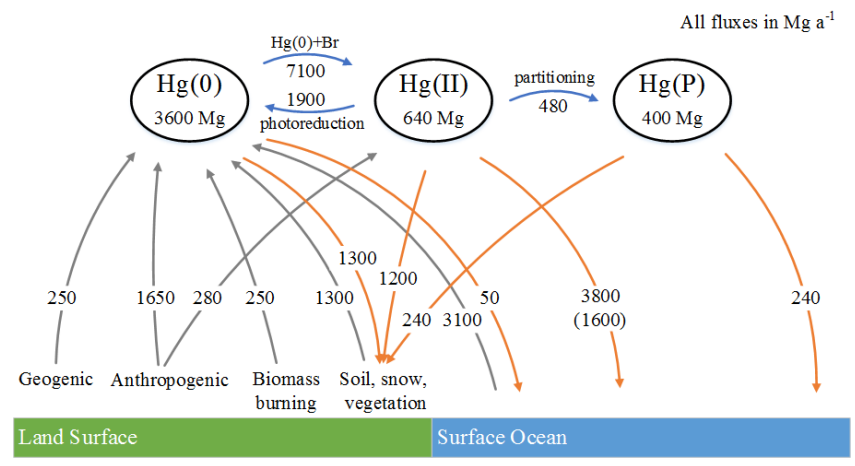

Figure 5. Global budget of atmospheric mercury derived from this study. The fluxes in parentheses indicate uptake of $\mathrm{Hg}$ (II) by seasalt aerosol.

polar regions when using the mercury $+\mathrm{Br}$ model (Holmes et al., 2010; Parrella et al., 2012).

Figure $4 \mathrm{~d}$ reveals that mercury dry deposition over continents also resembles the spatial emission pattern from the AMAP/UNEP emission inventory. East Asia, the Indian subcontinent, central Europe and southeast US are major depo- sition regions. Mercury dry deposition over oceans is largely from the uptake of $\mathrm{Hg}$ (II) by sea-salt aerosol, and mostly occurs in the Southern Hemisphere. The total fluxes over continents are approximately equal to those over oceans. Hot spots for mercury wet deposition are East Asia, the Indian subcontinent, East Africa, the north and southwest Pacific, and the Gulf of Guinea. Unlike dry deposition, high fluxes occur over some oceans for mercury wet deposition and total fluxes over oceans are 2.5 times more than those over continents. On a global scale, mercury wet deposition that comprises $42 \%$ of total mercury deposition is comparable but somewhat smaller than dry deposition. Total mercury deposition fluxes range from $1 \mu \mathrm{g} \mathrm{m}^{-2} \mathrm{a}^{-1}$ over some areas in the Antarctic to $77 \mu \mathrm{g} \mathrm{m}^{-2} \mathrm{a}^{-1}$ over some areas in East Asia.

\subsection{Global atmospheric mercury budget}

Figure 5 shows the global budget of atmospheric mercury derived from this study. Fluxes of some processes of mercury biogeochemical cycle in our global budget are similar to those presented in Holmes et al. (2010), Soerensen et al. (2010) and Amos et al. (2012). Anthropogenic emissions 
in this study are $1930 \mathrm{Mg} \mathrm{a}^{-1}$ and total emissions from land are $3730 \mathrm{Mg} \mathrm{a}^{-1}$. It should be noted that we increase the proportion of $\mathrm{Hg}(0)$ anthropogenic emissions and merge $\mathrm{Hg}(\mathrm{P})$ emissions with $\mathrm{Hg}(\mathrm{II})$ (based on the findings from Zhang et al. (2012) and Amos et al. (2012)) so $\mathrm{Hg}(0), \mathrm{Hg}(\mathrm{II})$, and $\mathrm{Hg}(\mathrm{P})$ anthropogenic emissions in this study are different than those reported by Holmes et al. (2010) and Soerensen et al. (2010). Global atmospheric burdens are $3600 \mathrm{Mg} \mathrm{Hg}(0)$, $640 \mathrm{Mg} \mathrm{Hg}(\mathrm{II})$, and $400 \mathrm{MgHg}(\mathrm{P})$. The flux of $\mathrm{Hg}(0)$ to $\mathrm{Hg}$ (II) by $\mathrm{Br}$ oxidation is $7100 \mathrm{Mg} \mathrm{a}^{-1}$, which is similar to the value of $8000 \mathrm{Mg} \mathrm{a}^{-1}$ from Holmes et al. (2010) and Driscoll et al. (2013). However, because we adopt the incloud reduction rate constant from Amos et al. (2012), which is half that used by Holmes et al. (2010), the photoreduction flux of $\mathrm{Hg}(\mathrm{II})$ to $\mathrm{Hg}(0)$ is $1900 \mathrm{Mg} \mathrm{a}^{-1}$, nearly half that from Holmes et al. (2010) and Driscoll et al. (2013). From the amendment of $\mathrm{Hg}$ (II) partitioning between gas and particle phases, approximately $480 \mathrm{Mg} \mathrm{Hg}$ (II) converts to $\mathrm{Hg}(\mathrm{P})$ each year. The amendment to the mechanism of $\mathrm{Hg}(0)$ across the air-sea interface (discussed in Sect. 2.1) results in $\mathrm{Hg}(0)$ dry deposition to ocean being only $50 \mathrm{Mg} \mathrm{a}^{-1}$, which is significantly different than earlier global model predictions (Selin et al., 2008; Holmes et al., 2010; Corbitt et al., 2011). However, net $\mathrm{Hg}(0)$ ocean evasion is consistent with other studies ( $3050 \mathrm{Mg} \mathrm{a}^{-1}$ in this study, $2900 \mathrm{Mg} \mathrm{a}^{-1}$ from Amos et al. (2012), $3100 \mathrm{Mg} \mathrm{a}^{-1}$ from Amos et al. (2013), $2950 \mathrm{Mg} \mathrm{a}^{-1}$ from Soerensen et al. (2010), and $3000 \mathrm{Mg} \mathrm{a}^{-1}$ from Driscoll et al., 2013). Globally, mercury dry deposition is $2330 \mathrm{Mg} \mathrm{a}^{-1}$ (58\% $\mathrm{Hg}(0), 40 \% \mathrm{Hg}(\mathrm{II})$, and $2 \% \mathrm{Hg}(\mathrm{P})$ ), and wet deposition is $2900 \mathrm{Mg} \mathrm{a}^{-1}(85 \% \mathrm{Hg}$ (II), and $15 \%$ $\mathrm{Hg}(\mathrm{P}))$. Meanwhile, $1600 \mathrm{Mg} \mathrm{Hg}(\mathrm{II})$ is taken up by sea-salt aerosols and deposits to the ocean each year. The fluxes of mercury deposition and uptake by sea-salt aerosols are similar to those in Amos et al. (2012). To sum all emissions and deposition (deposition is assumed negative here) up, we estimate that nearly $1000 \mathrm{Mg}$ mercury is transported from land to the ocean and is sequestered by the ocean each year.

\subsection{Source-receptor relationships for surface mercury concentrations}

\subsubsection{Contributions from local and foreign sources}

The simulations are conducted under three scenarios: total, local, and background. "Total" refers to concentrations or deposition fluxes over a specific receptor region resulting from all global source emissions (exactly the same as the base case simulation discussed in Sect. 2.3). "Local" refers to those resulting from local anthropogenic emissions. "Background" denotes those owing to all sources except anthropogenic emissions from the receptor region, which consists of two categories: others and nature. "Others" includes anthropogenic emissions from the 10 regions other than the receptor region and nature refers to emissions from all global natural sources and untagged regions (the same as the nature tracer discussed in Sect. 2.3).

The average area-weighted (A-W) concentration from Liu et al. (2009a) is used in this study to quantify the average concentration over a specific region and is defined in Eq. (1). Then, the SMC over different regions are comparable.

$C_{\mathrm{aw}}=\frac{\sum_{i=1}^{n} C_{i} \cdot S_{i}}{\sum_{i=1}^{n} S_{i}}$

In Eq. (1), $C_{\text {aw }}$ is the A-W SMC over a receptor region $R$. The total number of grid boxes covered by region $R$ is $n, C_{i}$ is the SMC in grid box $i$ in region $R$ and $S_{i}$ is the area of grid box $i$ in region $R$. We also define the percent contributions of $C_{\text {aw }}$ (POC) using ratios of local or background to total for each receptor region.

Table 1 summarizes the A-W SMC over each receptor region from each source category (including total, local, and background), with all POCs for each receptor region. It indicates that $\mathrm{A}-\mathrm{W}$ surface $\mathrm{Hg}(0)$ concentrations over the 10 regions other than EA are mainly attributed to global natural sources $(>50 \%)$. For EA, local anthropogenic emissions are the predominant sources and comprise $41 \%$ of the total contributions. Thus, EA is the only region whose contributions from local anthropogenic emissions exceed foreign ones. Global anthropogenic emissions and transformation dominate $\mathrm{A}-\mathrm{W}$ surface $\mathrm{Hg}$ (II) concentrations over $\mathrm{EU}$, IN, and EA (>50\%), while in other regions they are dictated by global natural sources. Local emissions also play a dominant role in EU, IN, and EA, accounting for 52, 53, and 64\%, respectively. For $\mathrm{A}-\mathrm{W}$ surface $\mathrm{Hg}(\mathrm{P})$ concentrations, regions that are dominated by global anthropogenic emissions and transformation (>50\%) include NA, EU, RU, IN, and EA. Similarly to $\mathrm{Hg}(\mathrm{II})$, local emissions play a dominant role in these regions, especially in EU (66\%) and EA (71\%).

Natural sources include oceanic emissions, land reemissions and primary natural emissions, which account for two-thirds of the total emissions (Pirrone et al., 2010; $72 \%$ in this study). Besides, natural sources mainly emit $\mathrm{Hg}(0)$ (Selin et al., 2007, 2008). Therefore it is not surprising there are large contributions from global natural sources to surface $\mathrm{Hg}(0)$ concentrations over all regions. $\mathrm{Hg}(\mathrm{II})$ and $\mathrm{Hg}(\mathrm{P})$ show near-field transport and deposition, owing to their sufficient water solubility. Some regions (e.g., EA, IN, and EU), where large local anthropogenic emissions occur, should be responsible for their local surface $\mathrm{Hg}(\mathrm{II})$ and $\mathrm{Hg}(\mathrm{P})$ concentrations.

\subsubsection{Region of primary influence and region of secondary influence}

It is useful for global environmental policymakers to understand which foreign region's anthropogenic emissions have significant effects on a specific receptor region's SMC. To make this clear, we adopt the definition of region of primary 
Table 1. Contributions from local and foreign sources to annual average A-W SMC (including $\mathrm{Hg}(0), \mathrm{Hg}(\mathrm{II}), \mathrm{Hg}(\mathrm{P}))$ over each receptor region. The percent contributions (POC) that are defined using ratios of local or background to total are quantified.

\begin{tabular}{|c|c|c|c|c|c|c|c|c|c|c|c|c|c|}
\hline \multirow[t]{2}{*}{ Sources } & \multirow[t]{2}{*}{ Forms } & \multirow[t]{2}{*}{ Unit } & \multicolumn{11}{|c|}{ Receptors } \\
\hline & & & NA & SA & EU & RU & $\mathrm{AF}$ & IN & EA & SE & $\mathrm{AU}$ & ME & MA \\
\hline \multirow[t]{3}{*}{ Total $^{\mathrm{a}}$} & $\mathrm{Hg}(0)$ & $\mathrm{ng} \mathrm{m}^{-3}$ & 1.45 & 1.14 & 1.59 & 1.53 & 1.19 & 1.41 & 1.97 & 1.29 & 0.97 & 1.32 & 1.48 \\
\hline & $\mathrm{Hg}(\mathrm{II})$ & $\mathrm{pg} \mathrm{m}^{-3}$ & 13.71 & 9.75 & 11.35 & 12.48 & 14.79 & 43.05 & 29.26 & 5.28 & 18.38 & 21.44 & 16.56 \\
\hline & $\mathrm{Hg}(\mathrm{P})$ & $\mathrm{pg} \mathrm{m}^{-3}$ & 2.36 & 0.86 & 9.93 & 8.80 & 12.66 & 18.28 & 48.58 & 0.80 & 3.47 & 18.89 & 15.87 \\
\hline \multirow[t]{6}{*}{ Local $^{b}$} & $\mathrm{Hg}(0)$ & $\mathrm{ng} \mathrm{m}^{-3}$ & 0.08 & 0.08 & 0.18 & 0.11 & 0.04 & 0.24 & 0.81 & 0.11 & 0.02 & 0.05 & 0.07 \\
\hline & & $\%$ & 5 & 7 & 11 & 7 & 3 & 17 & 41 & 9 & 2 & 4 & 5 \\
\hline & $\mathrm{Hg}(\mathrm{II})$ & $\mathrm{pg} \mathrm{m}^{-3}$ & 2.70 & 0.99 & 5.90 & 3.05 & 1.25 & 22.79 & 18.63 & 1.31 & 1.06 & 2.09 & 2.13 \\
\hline & & $\%$ & 20 & 10 & 52 & 24 & 8 & 53 & 64 & 25 & 6 & 10 & 13 \\
\hline & $\mathrm{Hg}(\mathrm{P})$ & $\mathrm{pg} \mathrm{m}^{-3}$ & 0.96 & 0.07 & 6.59 & 4.05 & 0.52 & 8.81 & 34.72 & 0.15 & 0.14 & 1.65 & 2.40 \\
\hline & & $\%$ & 41 & 9 & 66 & 46 & 4 & 48 & 71 & 18 & 4 & 9 & 15 \\
\hline \multirow{6}{*}{$\begin{array}{l}\text { Background } \\
\text { (Others) }\end{array}$} & $\mathrm{Hg}(0)$ & $n g m^{-3}$ & 0.39 & 0.18 & 0.41 & 0.44 & 0.28 & 0.31 & 0.22 & 0.32 & 0.15 & 0.39 & 0.46 \\
\hline & & $\%$ & 27 & 16 & 26 & 29 & 24 & 22 & 11 & 25 & 16 & 30 & 31 \\
\hline & $\mathrm{Hg}(\mathrm{II})$ & $\mathrm{pg} \mathrm{m}^{-3}$ & 3.31 & 1.86 & 2.10 & 3.18 & 3.62 & 5.74 & 2.27 & 1.13 & 3.74 & 6.18 & 5.36 \\
\hline & & $\%$ & 24 & 19 & 18 & 25 & 24 & 13 & 8 & 21 & 20 & 29 & 32 \\
\hline & $\mathrm{Hg}(\mathrm{P})$ & $\mathrm{pg} \mathrm{m}^{-3}$ & 0.42 & 0.17 & 1.52 & 1.89 & 3.49 & 2.67 & 2.87 & 0.24 & 0.71 & 5.40 & 5.03 \\
\hline & & $\%$ & 18 & 20 & 15 & 22 & 28 & 15 & 6 & 30 & 20 & 29 & 32 \\
\hline \multirow{6}{*}{$\begin{array}{l}\text { Background } \\
\text { (Nature) }\end{array}$} & $\mathrm{Hg}(0)$ & $n g m^{-3}$ & 0.98 & 0.86 & 1.01 & 0.99 & 0.86 & 0.85 & 0.95 & 0.85 & 0.77 & 0.88 & 0.95 \\
\hline & & $\%$ & 68 & 76 & 64 & 65 & 72 & 60 & 48 & 66 & 80 & 67 & 64 \\
\hline & $\mathrm{Hg}(\mathrm{II})$ & $\mathrm{pg} \mathrm{m}^{-3}$ & 7.67 & 6.78 & 3.37 & 6.23 & 9.80 & 14.42 & 8.31 & 2.81 & 13.35 & 13.10 & 9.10 \\
\hline & & $\%$ & 56 & 70 & 30 & 50 & 66 & 33 & 28 & 53 & 73 & 61 & 55 \\
\hline & $\mathrm{Hg}(\mathrm{P})$ & $\mathrm{pg} \mathrm{m}^{-3}$ & 0.98 & 0.60 & 1.82 & 2.83 & 8.57 & 6.74 & 10.91 & 0.41 & 2.57 & 11.77 & 8.41 \\
\hline & & $\%$ & 42 & 70 & 18 & 32 & 68 & 37 & 22 & 51 & 74 & 62 & 53 \\
\hline
\end{tabular}

a "Total" refers to average A-W SMC over a receptor region resulting from all global source emissions.

$\mathrm{b}$ "Local" refers to average A-W SMC over a receptor region resulting from local anthropogenic emissions.

c "Background" denotes average A-W SMC over a receptor region resulting from all sources except anthropogenic emissions from the receptor region, including

anthropogenic emissions from the other 10 regions (others) and emissions from all global natural sources and untagged regions (nature).

influence (RPI) from Liu et al. (2009a). Because of high anthropogenic mercury emissions from EA (Fig. 2), EA is the SMC RPI for most regions in our simulations. Therefore, we define one source region as the region of secondary influence (RSI) on a given receptor region so that we can identify other influence patterns outside of those from EA. Calculations of RPIs and RSIs in this section are based on POC (defined in Sect. 3.4.1), where here POC is calculated using ratios of SMC originating from each foreign region to SMC originating from the total over a given receptor region. When all POCs are added together for a given receptor region, an equivalent value to the $\mathrm{POC}$ calculated using ratios of others to total for the receptor region in Table 1 is obtained.

Figure 6 illustrates intercontinental influence patterns based on the RPI and RSI for SMC. EA is the SMC $(\mathrm{Hg}(0)$, $\mathrm{Hg}(\mathrm{II})$, and $\mathrm{Hg}(\mathrm{P})) \mathrm{RPI}$ for the other 10 regions, except that RU is the surface $\mathrm{Hg}(\mathrm{P})$ concentration RPI for EU. EU, IN, and RU are the surface $\mathrm{Hg}(0), \mathrm{Hg}(\mathrm{II})$, and $\mathrm{Hg}(\mathrm{P})$ concentration RPIs, respectively, for EA. Their contributions are all extremely low $(0<\mathrm{POC}<5)$, indicating that local emissions influence EA significantly. For surface $\mathrm{Hg}(0)$ concentrations, there are three significant (POC > 15) RPI relation- ships (EA $\rightarrow$ RU, EA $\rightarrow$ SE and EA $\rightarrow \mathrm{NA}$ ), compared with only one significant RPI for surface $\mathrm{Hg}$ (II) concentrations $(\mathrm{EA} \rightarrow \mathrm{MA})$ and no significant RPI for surface $\mathrm{Hg}(\mathrm{P})$ concentrations. This indicates that $\mathrm{Hg}(0)$ is transported far from source regions, while $\mathrm{Hg}(\mathrm{II})$ and $\mathrm{Hg}(\mathrm{P})$ show local emissions and transport, which is consistent with the results in Sect. 3.4.1.

EU is the surface $\operatorname{Hg}(0)$ concentration RSI for NA, AF, $\mathrm{ME}$, and RU and is the dominant RSI source region for $\mathrm{Hg}(0)$. RU $\rightarrow$ EU and RU $\rightarrow$ MA are moderate RSI relationships $(5<\mathrm{POC}<10)$ regarding surface $\mathrm{Hg}(\mathrm{II})$ concentrations. For $\mathrm{Hg}(\mathrm{P})$, IN is the dominant RSI source region, which is RSI for EA, SE, AF, and ME. NA, AF, ME, MA, and $\mathrm{AU}$ are the primary receptor regions because they are not the RPI or RSI for any region. Overall, EA is responsible for SMC over almost all regions if contributions from their local anthropogenic emissions are not accounted for. However, EU, RU, and IN also make some contributions to SMC over the primary receptor regions (e.g., NA, AF, ME, MA, and $\mathrm{AU})$. 

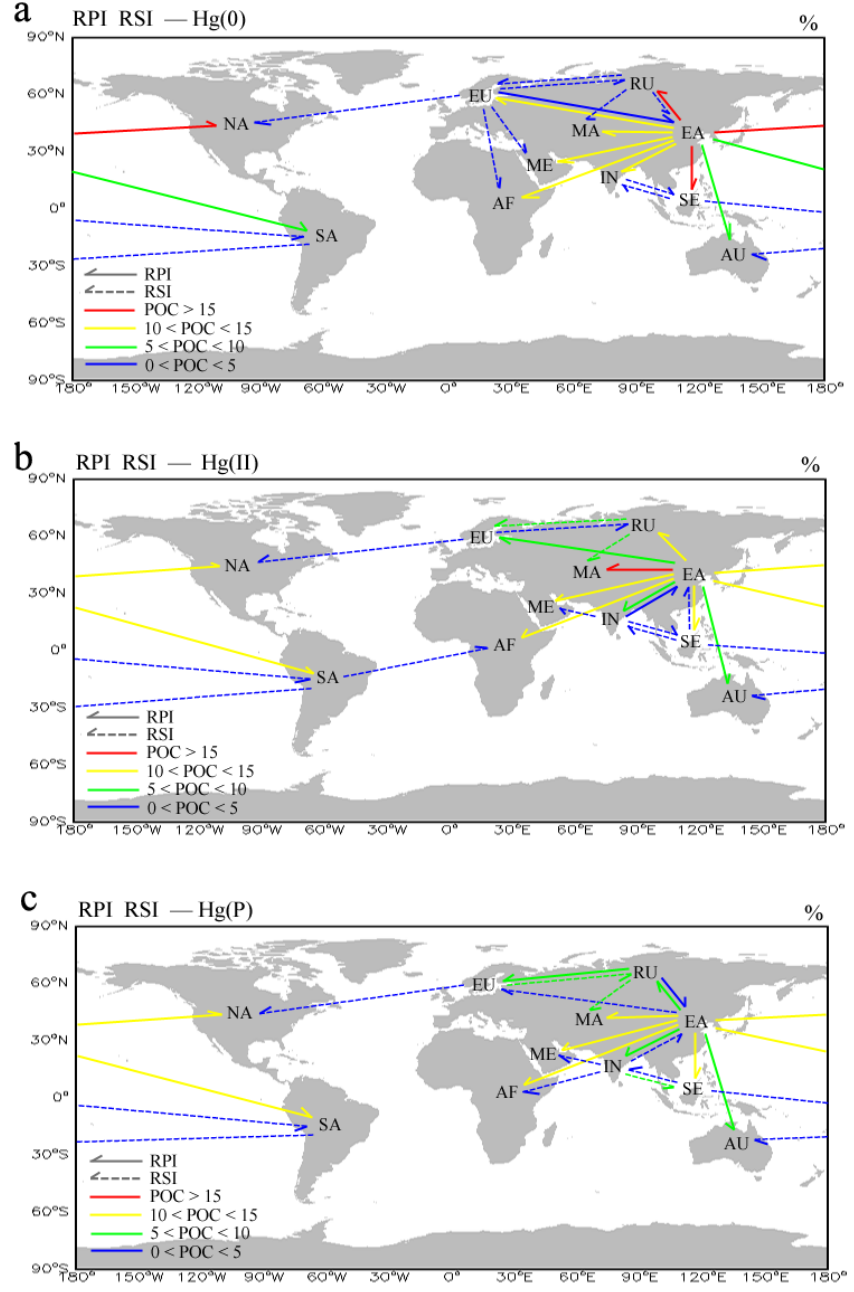

Figure 6. Intercontinental influence patterns based on the RPI (region of primary influence) and RSI (region of secondary influence) for SMC: (a) $\mathrm{Hg}(0)$; (b) $\mathrm{Hg}(\mathrm{II})$; (c) $\mathrm{Hg}(\mathrm{P})$. Arrows point in the direction of influence from the RPI or RSI to a receptor region. Colors indicate the magnitude of POC contributed from the RPI or RSI to a receptor region.

\subsection{Source-receptor relationships for mercury deposition}

\subsubsection{Contributions from local and foreign sources}

Similarly to Sect. 3.4, the categories of total, local, and background (including others, and nature) are used to identify intercontinental influence patterns for mercury deposition. For each region, we add the deposition fluxes in all grid boxes to obtain a total deposition. Here we define the percent contributions of deposition fluxes (POF) using ratios of local or background to total for each receptor region.

Table 2 shows that the total mercury deposition fluxes (including dry and wet) over each receptor region at the total category. Considerable efforts have been made towards the deposition over East Asia and North America (Philip et al., 2007; Jaffe and Strode, 2008; Lin et al., 2010). The annual average mercury dry and wet deposition over East Asia is 266.6 and $113.1 \mathrm{Mg}$, respectively. Contributions from anthropogenic sources to mercury dry and wet deposition over East Asia account for 62 and $54 \%$, respectively. For North America, the total mercury deposition is $437.4 \mathrm{Mg} \mathrm{a}^{-1}$ (292.7 $\mathrm{Mg} \mathrm{a}^{-1}$ for dry deposition and $144.7 \mathrm{Mg} \mathrm{a}^{-1}$ for wet deposition).

Table 2 also summarizes the mercury deposition fluxes over each receptor region from each source category (including total, local, and background), with all POFs for each receptor region. It shows that global natural sources dominate mercury dry deposition over all regions (>50\%) except IN and EA. For the nine regions that are mainly affected by global natural sources, contributions from foreign anthropogenic emissions all exceed local anthropogenic emissions, with only EU having nearly equal values. However, mercury dry deposition over IN and EA mainly originate from global anthropogenic emissions (> 50\%), with the primary contributions being from local emissions. Differences between local and foreign emissions are 14 and $44 \%$, respectively. Similarly to dry deposition, mercury wet deposition over all regions except EA are dictated by global natural sources $(>50 \%)$. For the 10 other regions, contributions from foreign anthropogenic emissions all exceed local anthropogenic emissions, with only IN having nearly equal values. EA is the only region whose contributions from anthropogenic sources are greater than natural sources and the difference between local and foreign emissions is $32 \%$.

Comparisons between mercury dry and wet deposition in Table 2 indicate that contributions from global natural sources to mercury dry deposition are approximately equal to those for wet deposition over each region, while contributions from local anthropogenic emissions to dry deposition exceed those for wet deposition. Conversely, dry deposition is lower than wet deposition for contributions from foreign anthropogenic emissions over each region. Overall, wet deposition occurs farther from source regions than dry deposition that mainly shows near-field occurrence.

\subsubsection{Region of primary influence and region of secondary influence}

The RPI and RSI are also used to understand source-receptor relationships for mercury deposition among the 11 regions. Similarly to POC in Sect. 3.4.2, POF is used to calculate the RPI and RSI in this section. The influence patterns are shown in Fig. 7. EA is the mercury dry and wet deposition RPI for the other 10 regions and IN is EA's RPI. It should be noted that EA is the significant mercury deposition (including dry and wet) RPI for NA, RU and MA (POF > 15). EA is the only significant dry deposition RPI for SE and the only significant wet deposition RPI for EU. For NA, approximately 16 and $17 \%$ of dry and wet deposition, respectively, originate from 
Table 2. Contributions from local and foreign sources to dry and wet deposition over each receptor region. The categories are defined same as Table 1 .

\begin{tabular}{|c|c|c|c|c|c|c|c|c|c|c|c|c|c|}
\hline \multirow[t]{2}{*}{ Sources } & \multirow[t]{2}{*}{ Forms } & \multirow[t]{2}{*}{ Unit } & \multicolumn{11}{|c|}{ Receptors } \\
\hline & & & NA & SA & EU & RU & $\mathrm{AF}$ & IN & EA & SE & $\mathrm{AU}$ & $\mathrm{ME}$ & MA \\
\hline \multirow[t]{2}{*}{ Total } & Dry & $\mathrm{Mg} \mathrm{a}^{-1}$ & 292.7 & 328.3 & 95.3 & 203.0 & 388.8 & 82.3 & 266.6 & 91.8 & 109.4 & 77.2 & 24.2 \\
\hline & Wet & $\mathrm{Mg} \mathrm{a}^{-1}$ & 144.7 & 158.4 & 43.2 & 97.5 & 187.7 & 57.4 & 113.1 & 68.4 & 66.4 & 37.6 & 10.5 \\
\hline \multirow[t]{4}{*}{ Local } & Dry & $\mathrm{Mg} \mathrm{a}^{-1}$ & 32.2 & 23.1 & 21.2 & 18.5 & 17.7 & 26.5 & 141.7 & 13.1 & 5.3 & 4.7 & 1.3 \\
\hline & Dry & $\%$ & 11 & 7 & 22 & 9 & 5 & 32 & 53 & 14 & 5 & 6 & 6 \\
\hline & Wet & $\mathrm{Mg} \mathrm{a}^{-1}$ & 8.5 & 6.1 & 5.1 & 5.4 & 5.0 & 11.8 & 48.2 & 4.0 & 0.9 & 1.2 & 0.2 \\
\hline & Wet & $\%$ & 6 & 4 & 12 & 6 & 3 & 21 & 43 & 6 & 1 & 3 & 2 \\
\hline \multirow{4}{*}{$\begin{array}{l}\text { Background } \\
\text { (Others) }\end{array}$} & Dry & $\mathrm{Mg} \mathrm{a}^{-1}$ & 77.2 & 56.5 & 23.4 & 60.5 & 89.6 & 15.1 & 23.5 & 23.1 & 19.2 & 22.9 & 7.8 \\
\hline & Dry & $\%$ & 26 & 17 & 25 & 30 & 23 & 18 & 9 & 25 & 18 & 30 & 32 \\
\hline & Wet & $\mathrm{Mga}^{-1}$ & 41.3 & 34.2 & 12.1 & 31.3 & 48.1 & 12.6 & 12.5 & 16.4 & 14.7 & 10.9 & 3.3 \\
\hline & Wet & $\%$ & 29 & 22 & 28 & 32 & 26 & 22 & 11 & 24 & 22 & 29 & 31 \\
\hline \multirow{4}{*}{$\begin{array}{l}\text { Background } \\
\text { (Nature) }\end{array}$} & Dry & $\mathrm{Mg} \mathrm{a}^{-1}$ & 183.9 & 244.6 & 51.6 & 125.4 & 278.2 & 40.3 & 101.1 & 54.9 & 83.1 & 49.4 & 15.1 \\
\hline & Dry & $\%$ & 63 & 74 & 54 & 62 & 72 & 49 & 38 & 60 & 76 & 64 & 62 \\
\hline & Wet & $\mathrm{Mg} \mathrm{a}^{-1}$ & 94.4 & 116.1 & 26.0 & 60.8 & 133.1 & 32.7 & 52.1 & 47.3 & 49.7 & 25.3 & 6.9 \\
\hline & Wet & $\%$ & 65 & 73 & 60 & 62 & 71 & 57 & 46 & 69 & 75 & 67 & 66 \\
\hline
\end{tabular}

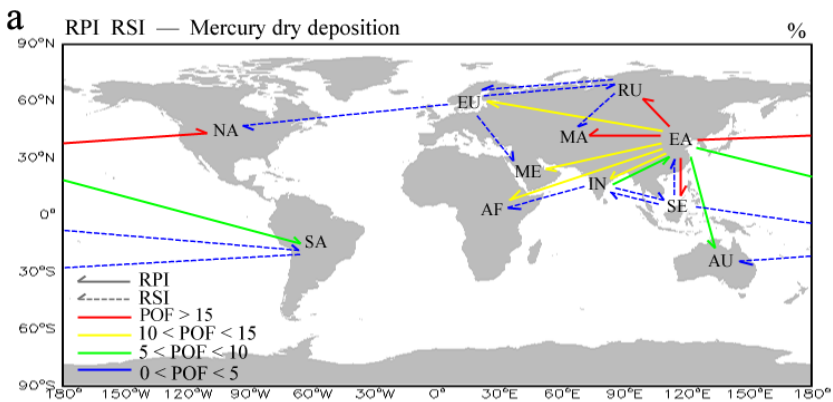

$\mathrm{b}_{90^{\circ} \mathrm{N}}$ RPI RSI - Mercury wet deposition

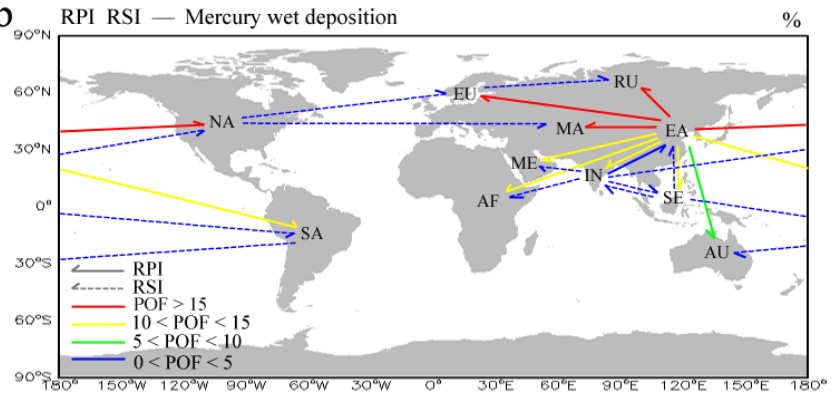

Figure 7. Intercontinental influence patterns based on the RPI (region of primary influence) and RSI (region of secondary influence) for mercury deposition: (a) mercury dry deposition; (b) mercury wet deposition. The arrows and colors are defined same as Fig. 5.

EA, consistent with 7-20\% (average 16\%) from Jaffe and Strode (2008). It also indicates that transpacific transport of EA emissions is the major foreign source of mercury deposition in NA, which is in agreement with previous findings (Seigneur et al., 2004; Selin and Jacob, 2008; Strode et al., 2008). Compared with NA, the dry and wet deposition con- tributions from EA are 17 and $18 \%$, respectively, for RU and 15 and $16 \%$, respectively, for MA.

For mercury dry deposition, EU and SE both have three RSI relationships for other receptor regions and IN is the mercury wet deposition RSI for AF, SE, NA and ME, making it the dominant RSI source region for wet deposition. EU, SE and IN are also important mercury deposition source regions for some receptor regions (e.g., $\mathrm{AU}, \mathrm{AF}, \mathrm{ME}$, and MA) except EA. The two RSI relationships (NA $\rightarrow$ EU and $\mathrm{NA} \rightarrow \mathrm{MA}$ ) indicate that NA mainly acts as a primary receptor region for SMC and mercury dry deposition, but it acts as a secondary source region for mercury wet deposition.

\subsection{Seasonal variation on mercury deposition contributions over other regions from East Asia}

As the largest source region, EA strongly affects the spatial distribution of global atmospheric mercury because of its substantial anthropogenic emissions. However, temporal variation of influence patterns on other regions from EA is also important to understand. To understand the temporal variation of influence patterns on the 10 receptor regions from EA, we calculate seasonal POFs of mercury dry and wet deposition for each receptor region. Combined with their annual POFs from EA, we quantify seasonal patterns among them (Fig. 8).

Figure 8 a illustrates that mercury dry deposition contributions over the 10 receptor regions from EA have two seasonal patterns. First, NA, EU, RU, ME and MA (black filled marks) have low values (seasonal POF < annual POF) in winter and high values (seasonal POF > annual POF) in summer. RU is a typical region whose wintertime POF is only half that of its summertime POF. Second, other regions, such as SE and IN, 

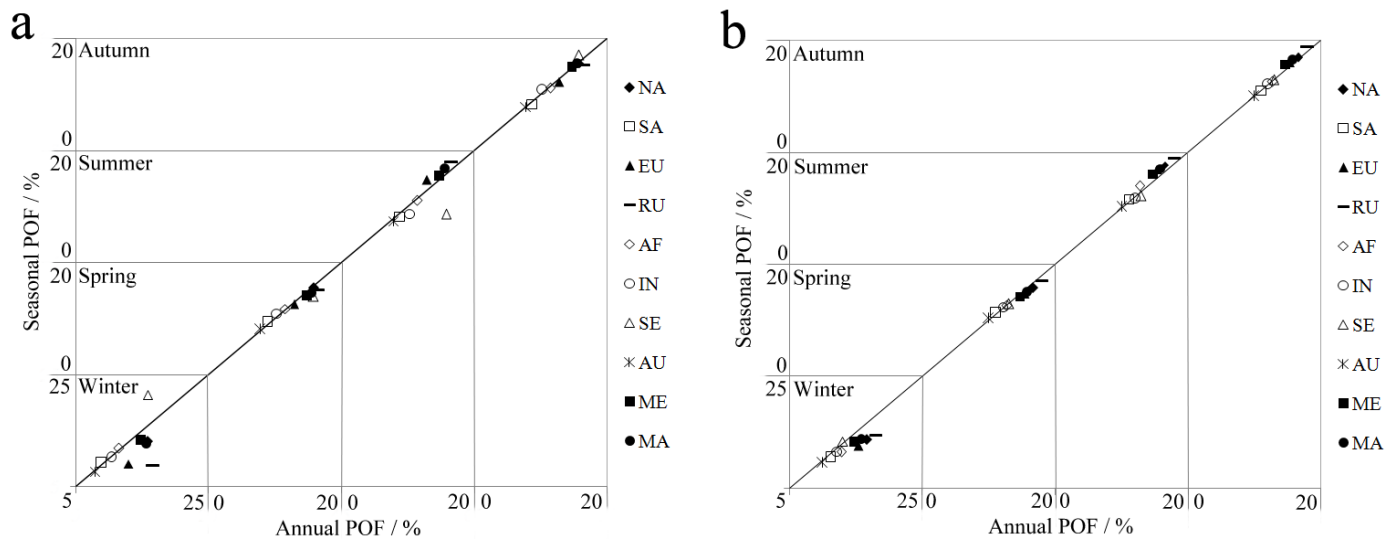

Figure 8. Seasonal variation on mercury deposition contributions over other regions from East Asia (EA): (a) mercury dry deposition; (b) mercury wet deposition. Four period zones are defined (winter, spring, summer, and autumn) and each period zone has its own ranges of POF values. The line is for equivalence between seasonal POF and annual POF.

have low values in summer and high values in other seasons (SE in winter and IN in spring). SE is a typical region whose POF in winter is nearly 3 times that of its summertime value. Seasonal variation on dry deposition contributions over the remaining regions is not apparent. Figure $8 \mathrm{~b}$ shows that seasonal variation on mercury wet deposition contributions over NA, EU, RU, ME, and MA (black filled marks) from EA is similar to the results for dry deposition. Slightly higher values in autumn are the only difference. Compared with dry deposition, seasonal variation on wet deposition contributions over the remaining regions (no filled marks) is not apparent, including SE and IN.

Mercury deposition (including dry and wet) contributions from EA over the Northern Hemisphere receptor regions (e.g., NA, EU, RU, ME, and MA) vary seasonally, with the maximum values in summer and minimum values in winter. When low contributions originate from EA, contributions from local emissions dominate mercury deposition in these regions. In summer, high concentrations of oxidant $(\mathrm{Br}$ atoms) in the Northern Hemisphere result in active mercury chemical reactions, contributing to more deposition (Holmes et al., 2006, 2010; Parrella et al., 2012). However, mercury dry deposition contributions over SE and IN from EA have the opposite seasonal pattern. For SE, the monsoon climate in EA may contribute to this difference. Also, the QinghaiTibet Plateau may affect the seasonal pattern over IN. More studies should be conducted about the impact of the monsoon climate in EA on the transport of atmospheric mercury from EA to SE and the impact of the Qinghai-Tibet Plateau on the transport of atmospheric mercury between EA and IN.

\section{Conclusions}

With growing concerns about the influence of intercontinental transport and deposition of air pollutants, a quantitative and comprehensive understanding of influence patterns for mercury is needed. In this study, we tag emissions of $\operatorname{Hg}(0)$, $\mathrm{Hg}(\mathrm{II})$, and $\mathrm{Hg}(\mathrm{P})$ emitted from 11 continental regions and use the GEOS-Chem model (v9-01-03) and AMAP/UNEP emission inventory to evaluate the intercontinental transport and deposition patterns of atmospheric mercury from anthropogenic emissions. Compared with previous GEOSChem versions (e.g., v8-03-02, and v9-01-02), we obtain $1900 \mathrm{Mg} \mathrm{a}^{-1}$ for $\mathrm{Hg}$ (II) photoreduction in clouds. Approximately $480 \mathrm{Mg} \mathrm{Hg}$ (II) converts to $\mathrm{Hg}(\mathrm{P})$ through partitioning and nearly $1000 \mathrm{Mg}$ mercury is transported from land to the ocean and is sequestered by the ocean each year.

For each continental region, contributions from local and foreign sources are quantified and intercontinental influence patterns are established for area-weighted (A-W) surface mercury concentrations (SMC) using the definition of region of primary influence (RPI) and region of secondary influence (RSI). Global natural sources are the dominant sources to A-W surface $\operatorname{Hg}(0)$ concentrations over all regions except EA. For EA, local anthropogenic emissions are the dominant sources and comprise $41 \%$ of total contributions. Results show that some regions (e.g., EA, IN, and EU) should be responsible for their local surface $\mathrm{Hg}(\mathrm{II})$ and $\mathrm{Hg}(\mathrm{P})$ concentrations because of high contributions from local anthropogenic emissions. EA is the SMC RPI for all other regions, except that RU is the surface $\mathrm{Hg}(\mathrm{P})$ concentrations RPI for EU. For surface $\operatorname{Hg}(0)$ concentrations, there are three significant RPI relationships (EA $\rightarrow \mathrm{RU}, \mathrm{EA} \rightarrow \mathrm{SE}$ and $\mathrm{EA} \rightarrow \mathrm{NA}$ ), with only one for $\mathrm{Hg}(\mathrm{II})(\mathrm{EA} \rightarrow \mathrm{MA})$ and none for $\mathrm{Hg}(\mathrm{P})$. $\mathrm{EU}$ is the dominant RSI source region for $\mathrm{Hg}(0)$, with IN the dominant RSI for $\mathrm{Hg}(\mathrm{P})$. RU $\rightarrow \mathrm{EU}$ and $\mathrm{RU} \rightarrow \mathrm{MA}$ are moderate RSI relationships regarding $\mathrm{Hg}$ (II). Generally, EA is responsible for SMC over almost every region, while EU, RU, and IN also make some contributions to SMC over other receptor regions (e.g., NA, AF, ME, MA, and AU).

Similarly to SMC, the contributions from local and foreign sources are quantified and intercontinental influence 
patterns are established for mercury deposition. Global natural sources are the main contributors for dry deposition over all regions except IN and EA, and for wet deposition over all regions except EA. Dry deposition over IN and EA are dictated by anthropogenic emissions, with differences between local and foreign emissions of 14 and $44 \%$, respectively. Difference between local and foreign emissions is $32 \%$ for the contributions from anthropogenic sources to wet deposition over EA. EA is the mercury deposition RPI for the other 10 regions, being the significant dry deposition RPI for NA, RU, MA and SE, and wet deposition RPI for NA, RU, MA, and EU. Approximately 16 and $17 \%$ of dry and wet deposition, respectively, over NA originate from EA, indicating that transpacific transport of EA emissions is the major foreign source of mercury deposition in NA. EU and SE both have three dry deposition RSI relationships for other receptor regions, while IN is the dominant wet deposition RSI source region. EU, SE, and IN are also responsible for some receptor regions' mercury deposition.

Seasonal variation on mercury deposition contributions over other regions from EA is quantified. Mercury deposition (including dry and wet) contributions from EA over the Northern Hemisphere receptor regions (e.g., NA, EU, RU, $\mathrm{ME}$, and MA) vary seasonally, with the maximum values in summer and minimum values in winter. However, the opposite seasonal pattern occurs on mercury dry deposition contributions over SE and IN from EA. Generally, international efforts that strengthen bilateral cooperation between receptor regions and their RPI or RSI (especially EA) to reduce mercury emissions are necessary to address global mercury pollution, and policymakers should also be aware of temporal patterns affecting receptor regions from source regions.

Acknowledgements. This study was funded by the National Natural Science Foundation of China (41130535, 41471403).

Edited by: C. Barbante

\section{References}

AMAP/UNEP: Technical Background Report for the Global Mercury Assessment 2013. Arctic Monitoring and Assessment Programme, Oslo, Norway/UNEP Chemicals Branch, Geneva, Switzerland, vi + 263 pp., 2013.

AMNet: NADP's Atmospheric Mercury Network: Moving toward Total Mercury Deposition, National Atmospheric Deposition Program, Illinois State Water Survey, Champaign, IL (http:// nadp.sws.uiuc.edu/amn/) (last access: 20 May 2014), 2009.

Amos, H. M., Jacob, D. J., Holmes, C. D., Fisher, J. A., Wang, Q., Yantosca, R. M., Corbitt, E. S., Galarneau, E., Rutter, A. P., Gustin, M. S., Steffen, A., Schauer, J. J., Graydon, J. A., Louis, V. L. St., Talbot, R. W., Edgerton, E. S., Zhang, Y., and Sunderland, E. M.: Gas-particle partitioning of atmospheric $\mathrm{Hg}$ (II) and its effect on global mercury deposition, Atmos. Chem. Phys., 12, 591-603, doi:10.5194/acp-12-591-2012, 2012.
Amos, H. M., Jacob, D. J., Streets, D. G., and Sunderland, E. M.: Legacy impacts of all-time anthropogenic emissions on the global mercury cycle, Global Biogeochem. Cy., 27, 410-421, doi:10.1002/gbc.20040, 2013.

Calvert, J. G. and Lindberg, S. E.: Mechanisms of mercury removal by $\mathrm{O}-3$ and $\mathrm{OH}$ in the atmosphere, Atmos. Environ., 39, 33553367, doi:10.1016/j.atmosenv.2005.01.055, 2005.

CAMNet, Canadian Atmospheric Mercury Measurement Network: Environment Canada, available at: http://www.ec.gc.ca/ natchem/default.asp?lang=En\&n=BFF7F7EE-1, (last access: 20 May 2014), 2011.

Chand, D., Jaffe, D., Prestbo, E., Swartzendruber, P. C., Hafner, W., Weiss-Penzias, P., Kato, S., Takami, A., Hatakeyama, S., and Kajii, Y.: Reactive and particulate mercury in the Asian marine boundary layer, Atmos. Environ., 42, 7988-7996, 2008.

Chin, Mian, Diehl, T., Ginoux, P., and Malm, W.: Intercontinental transport of pollution and dust aerosols: implications for regional air quality, Atmos. Chem. Phys., 7, 5501-5517, doi:10.5194/acp7-5501-2007, 2007.

Ci, Z. J., Zhang, X. S., Wang, Z. W., and Niu, Z. C.: Atmospheric gaseous elemental mercury (GEM) over a coastal/rural site downwind of East China: temporal variation and long-range transport, Atmos. Environ., 45, 2480-2487, 2011a.

Ci, Z. J., Zhang, X. S., Wang, Z. W., Niu, Z. C., Diao, X. Y., and Wang, S. W.: Distribution and air-sea exchange of mercury (Hg) in the Yellow Sea, Atmos. Chem. Phys., 11, 2881-2892, doi:10.5194/acp-11-2881-2011, 2011 b.

Corbitt, E. S., Jacob, D. J., Holmes, C. D., Streets, D. G., and Sunderland, E. M.: Global source-receptor relationships for mercury deposition under present-day and 2050 emissions scenarios, Environ. Sci. Technol., 45, 10477-10484, doi:10.1021/es202496y, 2011.

Driscoll, C. T., Mason, R. P., Chan, H. M., Jacob, D. J., and Pirrone, N.: Mercury as a Global Pollutant: Sources, Pathways, Effects and Policies, Environ. Sci. Technol., 47, 4967-4983, doi:10.1021/es305071v, 2013.

Edgerton, E. S., Hartsell, B. E., and Jansen, J. J.: Mercury speciation in coal-fired power plant plumes observed at three surface sites in the southeastern US, Environ. Sci. Technol., 40, 4563-4570, doi:10.1021/es0515607, 2006.

EMEP, The European Monitoring and Evaluation Programme: Convention on Long-range Transboundary Air Pollution, available at: http://www.nilu.no/projects/ccc/index.html, (last access: 20 May 2014), 2013.

Fitzgerald, W. F., Engstrom, D. R., Lamborg, C. H., Tseng, C. M., Balcom, P. H., and Hammerschmidt, C. R.: Modern and historic atmospheric mercury fluxes in northern Alaska: Global sources and Arctic depletion, Environ. Sci. Technol., 39, 557568, doi:10.1021/es049128x, 2005.

Fu, X. W., Feng, X. B., Zhu, W. Z., Wang, S. F., and Lu, J. L.: Total gaseous mercury concentrations in ambient air in the eastern slope of Mt. Gongga, south-eastern fringe of the Tibetan plateau, China, Atmos. Environ., 42, 970-979, 2008a.

Fu, X. W., Feng, X. B., Zhu, W. Z., Zheng, W., Wang, S. F., and Lu, J. Y.: Total particulate and reactive gaseous mercury in ambient air on the eastern slope of the Mt. Gongga area, China, Appl. Geochem., 23, 408-418, 2008b.

Fu, X. W., Feng, X. B., Zhu, W. Z., Rothenberg, S., Yao, H., and Zhang, H.: Elevated atmospheric deposition and dynamics of 
mercury in a remote upland forest of southwestern China, Environ. Pollut., 158, 2324-2333, 2010.

GMOS: http://www.gmos.eu, last access: 16 July 2014.

Holmes, C. D., Jacob, D. J., and Yang, X.: Global lifetime of elemental mercury against oxidation by atomic bromine in the free troposphere, Geophys. Res. Lett., 33, L20808, doi:10.1029/2006GL027176, 2006.

Holmes, C. D., Jacob, D. J., Mason, R. P., and Jaffe, D. A.: Sources and deposition of reactive gaseous mercury in the marine atmosphere, Atmos. Environ., 43, 2278-2285, doi:10.1016/j.atmosenv.2009.01.051, 2009.

Holmes, C. D., Jacob, D. J., Corbitt, E. S., Mao, J., Yang, X., Talbot, R., and Slemr, F.: Global atmospheric model for mercury including oxidation by bromine atoms, Atmos. Chem. Phys., 10, 12037-12057, doi:10.5194/acp-10-12037-2010, 2010.

Hynes, A., Donohoue, D., Goodsite, M., Hedgecock, I., Pirrone, N., and Mason, R.: Our current understanding of major chemical and physical processes affecting mercury dynamics in the atmosphere and at air-water/terrestrial interfaces, in: Mercury Fate and Transport in the Global Atmosphere, edited by: Pirrone, N. and Mason, R. P., chap. 14, Springer, 322-344, 2009.

Jaffe, D. and Strode, S.: Sources, fate and transport of atmospheric mercury from Asia, Environ. Chem., 5, 121-126, 2008.

Keeler, G. J., Gratz, L. E., and Al-Wali, K.: Long-term atmospheric mercury wet deposition at Underhill, Vermont, Ecotoxicology, 14, 71-83, doi:10.1007/s10646-004-6260-3, 2005.

Kim, S. H., Han, Y. J., Holsen, T. M., and Yi, S. M.: Characteristics of atmospheric speciated mercury concentrations (TGM, $\mathrm{Hg}$ (II) and $\mathrm{Hg}(\mathrm{p}))$ in Seoul, Korea, Atmos. Environ., 43, 3267-3274, doi:10.1016/j.atmosenv.2009.02.038, 2009.

Kos, G., Ryzhkov, A., and Dastoor, A.: Analysis of uncertainties in measurements and mode for oxidised and particle-bound mercury, 10th International Conference on Mercury as a Global Pollutant, Halifax, Nova Scotia, Canada, 2011.

Lamborg, C. H., Fitzgerald, W. F., O'Donnell, J., and Torgersen, T.: A non-steady-state compartmental model of globalscale mercury biogeochemistry with interhemispheric gradients, Geochim. Cosmochim. Ac., 66, 1105-1118, doi:10.1016/S00167037(01)00841-9, 2002.

Lin, C.-J., Pan, L., Streets, D. G., Shetty, S. K., Jang, C., Feng, X., Chu, H.-W., and Ho, T. C.: Estimating mercury emission outflow from East Asia using CMAQ-Hg, Atmos. Chem. Phys., 10, 1853-1864, doi:10.5194/acp-10-1853-2010, 2010.

Liu, H. Y., Jacob, D. J., Bey, I., and Yantosca, R. M.: Constraints from $\mathrm{Pb}-210$ and $\mathrm{Be}-7$ on wet deposition and transport in a global three-dimensional chemical tracer model driven by assimilated meteorological fields, J. Geophys. Res., 106, 1210912128, doi:10.1029/2000jd900839, 2001.

Liu, J. F. and Mauzerall, D. L.: Potential influence of intercontinental transport of sulfate aerosols on air quality, Environ. Res. Lett., 2, 045029, doi:10.1088/1748-9326/2/4/045029, 2007.

Liu, J. F., Mauzerall, D. L., Horowitz, L. W., Ginoux, P., and Fiore, A. M.: Evaluating inter-continental transport of fine aerosols: (1) Methodology, global aerosol distribution and optical depth, Atmos. Environ., 43, 4327-4338, doi:10.1016/j.atmosenv.2009.03.054, 2009a.

Liu, J. F., Mauzerall, D. L., and Horowitz, L. W.: Evaluating inter-continental transport of fine aerosols: (2)
Global health impact, Atmos. Environ., 43, 4339-4347, doi:10.1016/j.atmosenv.2009.05.032, 2009b.

Lohman, K., Seigneur, C., Edgerton, E., and Jansen, J.: Modeling mercury in power plant plumes, Environ. Sci. Technol., 40, 3848-3854, doi:10.1021/es051556v, 2006.

Lombard, M. A. S., Bryce, J. G., Mao, H., and Talbot, R.: Mercury deposition in Southern New Hampshire, 2006-2009, Atmos. Chem. Phys., 11, 7657-7668, doi:10.5194/acp-11-76572011, 2011.

Lyman, S. N. and Jaffe, D. A.: Formation and fate of oxidized mercury in the upper troposphere and lower stratosphere, Nat. Geosci., 5, 114-117, doi:10.1038/ngeo1353, 2012.

Mergler, D., Anderson, H. A., Chan, L. H. M., Mahaffey, K. R., Murray, M., Sakamoto, M., and Stern, A. H.: Methylmercury exposure and health effects in humans: a worldwide concern, Ambio, 36, 3-11, 2007.

Minamata Convention on Mercury: http://www.mercuryconvention. org, last access: 27 June 2014.

Pacyna, E. G., Pacyna, J. M., Steenhuisen, F., and Wilson, S.: Global anthropogenic mercury emission inventory for 2000, Atmos. Environ., 40, 4048-4063, doi:10.1016/j.atmosenv.2006.03.041, 2006.

Pacyna, E. G., Pacyna, J. M., Sundseth, K., Munthe, J., Kindbom, K., Wilson, S., Steenhuisen, F., and Maxson, P.: Global emission of mercury to the atmosphere from anthropogenic sources in 2005 and projections to 2020, Atmos. Environ., 44, 2487-2499, doi:10.1016/j.atmosenv.2009.06.009, 2010.

Pan, L., Lin, C. J., Carmichael, G. R., Streets, D. G., Tang, Y. H., Woo, J. H., Shetty, S. K., Chu, H. W., Ho, T. C., Friedli, H. R., and Feng, X. B.: Study of atmospheric mercury budget in East Asia using STEM-Hg modeling system, Sci. Total Environ., 408, 3277-3291, doi:10.1016/j.scitotenv.2010.04.039, 2010.

Parrella, J. P., Jacob, D. J., Liang, Q., Zhang, Y., Mickley, L. J., Miller, B., Evans, M. J., Yang, X., Pyle, J. A., Theys, N., and Van Roozendael, M.: Tropospheric bromine chemistry: implications for present and pre-industrial ozone and mercury, Atmos. Chem. Phys., 12, 6723-6740, doi:10.5194/acp-12-6723-2012, 2012.

Philip, K. G., Deyong, W., Fan, M., Fuquan, Y., and James, J. S.: Modeling of mercury emission, transport and deposition in North America, Atmos. Environ., 41, 1135-1149, doi:10.1016/j.atmosenv.2006.10.005, 2007.

Pirrone, N., Cinnirella, S., Feng, X., Finkelman, R. B., Friedli, H. R., Leaner, J., Mason, R., Mukherjee, A. B., Stracher, G. B., Streets, D. G., and Telmer, K.: Global mercury emissions to the atmosphere from anthropogenic and natural sources, Atmos. Chem. Phys., 10, 5951-5964, doi:10.5194/acp-10-59512010, 2010.

Rolfhus, K. R., Sakamoto, H. E., Cleckner, L. B., Stoor, R. W., Babiarz, C. L., Back, R. C., Manolopoulos, H., and Hurley, J. P.: Distribution and fluxes of total and methylmercury in Lake Superior, Environ. Sci. Technol., 37, 865-872, doi:10.1021/es026065e, 2003.

Roos-Barraclough, F., Martinez-Cortizas, A., Garcia-Rodeja, E., and Shotyk, W.: A 14500 year record of the accumulation of atmospheric mercury in peat: volcanic signals, anthropogenic influences and a correlation to bromine accumulation, Earth Planet. Sc. Lett., 202, 435-451, doi:10.1016/S0012-821X(02)00805-1, 2002. 
Schroeder, W. H. and Munthe, J.: Atmospheric mercury - An overview, Atmos. Environ., 32, 809-822, doi:10.1016/S13522310(97)00293-8, 1998.

Schuster, P. F., Krabbenhoft, D. P., Naftz, D. L., Cecil, L. D., Olson, M. L., Dewild, J. F., Susong, D. D., Green, J. R., and Abbott, M. L.: Atmospheric mercury deposition during the last 270 years: A glacial ice core record of natural and anthropogenic sources, Environ. Sci. Technol., 36, 2303-2310, doi:10.1021/es0157503, 2002.

Seigneur, C., Karamchandani, P., Vijayaraghavan, K., Lohman, K., Shia, R. L., and Levin, L.: On the effect of spatial resolution on atmospheric mercury modeling, Sci. Total Environ., 304, 73-81, doi:10.1016/s0048-9697(02)00558-2, 2003.

Seigneur, C., Vijayaraghavan, K., Lohman, K., Karamchandani, P., and Scott, C.: Global source attribution for mercury deposition in the United States, Environ. Sci. Technol., 38, 555-569, doi:10.1021/es034109t, 2004.

Seigneur, C., Vijayaraghavan, K., and Lohman, K.: Atmospheric mercury chemistry: Sensitivity of global model simulations to chemical reactions, J. Geophys. Res., 111, D22306, doi:10.1029/2005jd006780, 2006.

Selin, N. E. and Jacob D. J.: Seasonal and spatial patterns of mercury wet deposition in the United States: constraints on the contribution from North American anthropogenic sources, Atmos. Environ., 42, 5193-5204, doi:10.1016/j.atmosenv.2008.02.069, 2008.

Selin, N. E., Jacob, D. J., Park, R. J., Yantosca, R. M., Strode, S., Jaegle, L., and Jaffe, D.: Chemical cycling and deposition of atmospheric mercury: Global constraints from observations, J. Geophys. Res., 112, D02308, doi:10.1029/2006JD007450, 2007.

Selin, N. E., Jacob, D. J., Yantosca, R. M., Strode, S., Jaegle, L., and Sunderland, E. M.: Global 3-D land-ocean-atmosphere model for mercury: present-day versus preindustrial cycles and anthropogenic enrichment factors for deposition, Global Biogeochem. Cy., 22, GB2011, doi:10.1029/2007GB003040, 2008.

Selin, N. E. Sunderland, E. M., Knightes, C. D., and Mason, R. P.: Sources of Mercury Exposure for U.S. Seafood Consumers: Implications for Policy, Environ. Health Persp., 118, 137-143, doi:10.1289/ehp.0900811, 2010.

Sigler, J. M., Mao, H., and Talbot, R.: Gaseous elemental and reactive mercury in Southern New Hampshire, Atmos. Chem. Phys., 9, 1929-1942, doi:10.5194/acp-9-1929-2009, 2009.

Soerensen, A. L., Sunderland, E. M., Holmes, C. D., Jacob, D. J., Yantosca, R. M., Skov, H., Christensen, J. H., Strode, S. A., and Mason, R. P.: an Improved Global Model for Air-Sea Exchange of Mercury: High Concentrations over the North Atlantic, Environ. Sci. Technol., 44, 8574-8580, doi:10.1021/es102032g, 2010.

Soerensen, A. L., Jacob, D. J., Streets, D. G., Witt, M. L. I., Ebinghaus, R., Mason, R. P., Andersson, M., and Sunderland, E. M.: Multi-decadal decline of mercury in the North Atlantic atmosphere explained by changing subsurface seawater concentrations, Geophys. Res. Lett., 39, L21810, doi:10.1029/2012GL053736, 2012.

Strode, S. A., Jaegle, L., Jaffe, D. A., Swartzendruber, P. C., Selin, N. E., Holmes, C., and Yantosca, R. M.: Trans-Pacific transport of mercury, J. Geophys. Res.-Atmos., 113, D15305, doi:10.1029/2007JD009428, 2008.
Subir, M., Ariya, P. A., and Dastoor, A. P.: A review of uncertainties in atmospheric modeling of mercury chemistry I. Uncertainties in existing kinetic parameters - fundamental limitations and the importance of heterogeneous chemistry, Atmos. Environ., 45, 5664-5676, doi:10.1016/j.atmosenv.2011.04.046, 2011.

Temme, C., Slemr, F., Ebinghaus, R., and Einax, J. W.: Distribution of mercury over the Atlantic Ocean in 1996 and 19992001, Atmos. Environ., 37, 1889-1897, doi:10.1016/S13522310(03)00069-4, 2003.

TFHTAP: Hemispheric Transport of Air Pollution 2010, Part B: Mercury, United Nations Publication, ISBN: 978-92-1-1170443, 113-128, 2011.

UNEP: Global Mercury Assessment 2013: Sources, Emissions, Releases and Environmental Transport, UNEP Chemicals Branch, Geneva, Switzerland, 2013.

Vijayaraghavan, K., Karamchandani, P., Seigneur, C., Balmori, R., and Chen, S. Y.: Plume-in-grid modeling of atmospheric mercury, J. Geophys. Res., 113, D24305, doi:10.1029/2008jd010580, 2008.

Wan, Q., Feng, X. B., Lu, J., Zheng, W., Song, X. J., Li, P., Han, S. J., and $\mathrm{Xu}, \mathrm{H}$.: Atmospheric mercury in Changbai mountain area, northeastern china II: The distribution of reactive gaseous mercury and particulate mercury and mercury deposition fluxes, Environ. Res., 109, 721-727, 2009a.

Wan, Q., Feng, X. B., Lu, J. L., Zheng, W., Song, X. J., Han, S. J., and $\mathrm{Xu}, \mathrm{H}$.: Atmospheric mercury in Changbai mountain area, northeastern China I: The seasonal distribution pattern of total gaseous mercury and its potential sources, Environ. Res., 109, 201-206, 2009b.

Wang, Q., Jacob, D. J., Fisher, J. A., Mao, J., Leibensperger, E. M., Carouge, C. C., Le Sager, P., Kondo, Y., Jimenez, J. L., Cubison, M. J., and Doherty, S. J.: Sources of carbonaceous aerosols and deposited black carbon in the Arctic in winter-spring: implications for radiative forcing, Atmos. Chem. Phys., 11, 1245312473, doi:10.5194/acp-11-12453-2011, 2011.

Wang, Z. W., Chen, Z. S., Duan, N., and Zhang, X. S.: Gaseous elemental mercury concentration in atmosphere at urban and remote sites in china, J. Environ. Sci.-China, 19, 176-180, 2007.

Wesely, M. L.: Parameterization of surface resistances to gaseous dry deposition in regional-scale numerical-models, Atmos. Environ., 23, 1293-1304, doi:10.1016/0004-6981(89)90153-4, 1989.

Wilson, S. J., Steenhuisen, F., Pacyna, J. M., and Pacyna, E. G.: Mapping the spatial distribution of global anthropogenic mercury atmospheric emission inventories, Atmos. Environ., 40, 46214632, doi:10.1016/j.atmosenv.2006.03.042, 2006.

Zhang, H.: Concentrations of Speciated Atmospheric Mercury a High-altitude Background station in the Shangri-La area of Tibetan Plateau, China, in: 10th International Conference on Mercury as a Global Pollutant, Halifax, Canada, 2011.

Zhang, Y., Jaeglé, L., van Donkelaar, A., Martin, R. V., Holmes, C. D., Amos, H. M., Wang, Q., Talbot, R., Artz, R., Brooks, S., Luke, W., Holsen, T. M., Felton, D., Miller, E. K., Perry, K. D., Schmeltz, D., Steffen, A., Tordon, R., Weiss-Penzias, P., and Zsolway, R.: Nested-grid simulation of mercury over North America, Atmos. Chem. Phys., 12, 6095-6111, doi:10.5194/acp12-6095-2012, 2012. 